Ks. Antoni ŻUREK

(Tarnów, UPJPII)

\title{
KATECHEZA EUCHARYSTYCZNA ŚW. AUGUSTYNA
}

Proces wtajemniczenia chrześcijańskiego w Hipponie za czasów św. Augustyna obejmował, jak wiadomo, sakramenty: chrztu, bierzmowania, Eucharystii. Do ich przyjęcia katechumen przygotowywał się poprzez udział w katechezach przedchrzcielnych $\mathrm{i} w$ praktykach religijnych, jakie $\mathrm{z}$ nimi były związane ${ }^{1}$. Biskup Hippony w katechezach nie poruszał tematu sakramentów, co najwyżej w sposób bardzo oględny do nich tylko nawiązywał. Temat ten był zarezerwowany na czas następujący bezpośrednio po chrzcie. Wówczas, w katechezach o charakterze mistagogicznym, neofita był w nie wprowadzany. Praktyka ta dotyczyła nade wszystko misterium eucharystycznego. W katechezach przygotowujących do chrztu temat ten był tylko marginalnie poruszany.

1. Eucharystia w katechezie przedchrzcielnej. W katechezach głoszonych w ostatnim etapie przygotowania do chrztu biskup Augustyn objaśniał katechumenom treść wezwań Modlitwy Pańskiej i wśród nich wezwanie: „chleba naszego powszedniego daj nam dzisiaj”. Zdaniem Biskupa Hippony, przedmiotem tej prośby jest „,chleb”, który ma znaczenie wieloznaczne. Panis quotidianus to w pierwszym rzędzie synonim rzeczy materialnych i koniecznych do życia ${ }^{2}$. Ale w tym wezwaniu mamy też, a może nawet przede wszystkim, prosić o chleb dla naszego ducha. Tę dwuwymiarowość „chleba powszedniego" zgrabnie wyraził w jednej z katechez, mówiąc o chlebie napełniającym żołądek oraz o innym, którym karmiony jest duch ${ }^{3}$.

W opinii św. Augustyna, duch ludzki, podobnie jak ciało, też musi być odpowiednio wzmacniany i wymaga pokarmu na wzór chleba dla ciała. Chleb dla ducha jest konieczny człowiekowi w obecnej sytuacji, czyli w warunkach

${ }^{1}$ Szerzej zob. A. Żurek, Katecheza przedchrzcielna i mistagogiczna w Hipponie w czasach św. Augustyna, RBL 62 (2009) nr 1, 25-36.

${ }^{2}$ Augustyn wyraża to w różny sposób, por. Sermo 56, 6, 10, NBA 30/1, 150: „istum panem quo venter impletur, quo caro quotidie reficitur”; Sermo 57, 7, 7, NBA 30/1, 170: „Panis erit et ipse quotidianus, huic vitae necessarius”; Sermo 58, 4, 5, NBA 30/1, 186 ,quando rogamus panem quotidianus, quidquid nobis propter carnem nostram in terra necessarium est, postulamus"; Sermo 59, 3, 6, NBA 30/1, 204 ,in pane significantes quidquid nobis est necessarium”.

${ }^{3}$ Por. Augustinus, Sermo 56, 6, 10, NBA 30/1, 150: „Panis noster quotidianus est: inde vivunt non ventres, sed mentes". 
doczesności. „Chleb codzienny” (quotidianus), jak nazwany jest ten chleb, to synonim pokarmu doczesnego, potrzebnego w tym życiu (hodie), a nie wskazanie częstotliwości jego przyjmowania. Co jest takim chlebem? Św. Augustyn ujmuje to w sposób syntetyczny:

„Naszym pokarmem codziennym na tej ziemi, jest słowo Boże, które zawsze jest rozdzielane w Kościołach. [...] Jeżeli natomiast przez ten nasz chleb codzienny rozumiesz to, co wierni przyjmuja, co wy przyjmiecie jako ochrzczeni, to słusznie prosimy i mówimy «Chleba naszego codziennego daj nam dzisiaj», abyśmy tak żyli, byśmy od tego ołtarza nie zostali oddzieleni”"

Istnieją zatem dwa rodzaje pokarmu duchowego, potrzebnego człowiekowi w obecnej rzeczywistości. Jeden to ,słowo Boże”, czyli słowo zawarte w Piśmie Świętym i przepowiadane w Kościele ${ }^{5}$, a drugi pokarm, dostępny tylko ochrzczonym, przyjmuje się z ołtarza. Wprawdzie w katechezie nie pada nazwa tego chleba, ale można się domyślić, że chodzi o Eucharystię. Zresztą, w innej katechezie, wygłaszanej dla odrębnej grupy katechumenów, zostaje to powiedziane wprost:

„Wierzący znają także pokarm duchowy, który i wy macie poznać i przyjąć z ołtarza Bożego. Będzie chlebem i jednocześnie codziennym, koniecznym w tym życiu. Czyż bowiem będziemy przyjmować Eucharystię, gdy przyjdziemy do Chrystusa i zaczniemy z Nim królowanie wieczne? Zatem Eucharystia jest naszym chlebem codziennym".

Pokarm eucharystyczny, o który należy codziennie prosić, ma charakter doczesny, ponieważ:

„W tym czasie jest nam konieczny, gdy czujemy głód. Skoro bowiem będziemy w innym życiu, minie głód"’.

W życiu przyszłym, do którego zdążamy, Chrystus będzie dostępny już bez osłony chleba i wina. Natomiast obecnie pokarm eucharystyczny jest nam konieczny, stąd gorące zachęty naszego Biskupa kierowane do katechumenów, aby pospieszyli się z przygotowaniem do chrztu, bo inaczej nawet nie będą

${ }^{4}$ Augustinus, Sermo 56, 6, 10, NBA 30/1, 150: „Cibus noster quotidianus in hac terra, sermo Dei est, qui semper erogatur Ecclesiis [...] Iterum in isto pane quotidiano si intellegas quod fideles accipiunt, quo accepturi estis baptizati; bene rogamus et dicimus: Panem nostrum quotidianus da nobis hodie, ut sic vivamus, ne ab illo altari separemur".

${ }_{5}^{5}$ Augustinus, Sermo 59, 3, 6, NBA 30/1, 204: „Et verbum Dei quod quotidie praedicatur panis est”.

${ }^{6}$ Augustinus, Sermo 57, 7, 7, NBA 30/1, 170: „Norunt enim spiritalem alimoniam fideles, quam et vos scituri estis, accepturi de altare Dei. Panis erit et ipse quotidianus, huic vitae necessarius. Numquid enim Eucharistiam accepturi sumus, cum ad ipsum Christum venerimus, et cum illo in aeternum regnare coeperimus? Ergo Eucharistia panis noster quotidianus est”.

${ }^{7}$ Augustinus, Sermo 59, 3, 6, NBA 30/1, 204: „Hoc enim tempore est necessarius quando esurimus; cum autem in alia vita perimus, peribit fames".". 
wiedzieć na czym polega „spożywanie Ciała Pana i picie Jego Krwi”». Na etapie przygotowania nic więcej nie można im było powiedzieć. Katechumeni wiedzieli zatem, gdzie i kiedy będą mogli przyjąć prawdziwy „chleb z nieba” (J 6, 50), ale nie poznawali ani jego natury, ani nawet skąd się on bierze. Tego mogli się dowiedzieć dopiero po chrzcie.

2. Katecheza mistagogiczna w Kościele lacińskim. W Kościele łacińskim końca IV oraz początku $\mathrm{V}$ wieku jedyna i zamierzona edukacja eucharystyczna miała miejsce $w$ ramach pouczeń, udzielanych już nowo ochrzczonym, podczas sprawowania Eucharystii, w której oni już w pełni uczestniczyli. Taka katecheza była ściśle związana ze sprawowaną liturgią i stanowiła rodzaj komentarza do niej ${ }^{9}$. Zazwyczaj dopiero wówczas duszpasterze przybliżali neofitom istotę oraz objaśniali ryt wszystkich sakramentów, które oni już przyjęli ${ }^{10}$. Proces ten zwykło się nazywać mistagogią chrześcijańską ${ }^{11}$. „Wtajemniczenie” odbywało się w formie katechez-pouczeń, które przyjęło się nazywać katechezami mistagogicznymi. Wprawdzie mistagogia dotyczyła wszystkich sakramentów inicjacji chrześcijańskiej, ale Eucharystia zajmowała w niej miejsce uprzywilejowane. W ramach takich katechez następowało wprowadzenie nowo ochrzczonych w niektóre przynajmniej aspekty misterium eucharystycznego.

Takich kazań-katechez o charakterze mistagogicznym zachowało się w literaturze łacińskiej w sumie niewiele. Szerzej znane są jedynie katechezy św. Ambrożego i św. Augustyna. W spuściźnie po innych duszpasterzach zostały tylko pojedyncze kazania, nie zawsze w pełni zasługujące na miano katechez mistagogicznych ${ }^{12}$. Trudno wyrokować, czy w ogóle tak mało ich głoszono, czy też dokładano starań, aby nie zostały utrwalone na piśmie ${ }^{13}$. Bardzo prawdopodobna jednak jest ta pierwsza możliwość. Argumentem za tym przemawiającym zdają się być katechezy św. Ambrożego, zawarte w jego De sacramentis. Prawdopodobnie zawierają one całość nauczania przeznaczonego

${ }^{8}$ Augustinus, Sermo 132, 1, NBA 31/1, 204: „Quomodo manducatur caro Domini et bibitur sanguis Domini? [...] Accede ad professionem, et solvisti quaestionem".

${ }^{9}$ Szerzej zob. A. Triacca, Liturgia e catechesi nei Padri, „Salesianum” 41 (1975) nr 1, 262.

${ }^{10}$ Istniały jednak lokalne różnice, zwłaszcza dotyczące chrztu. Były Kościoły, gdzie obrzędy chrztu objaśniano przed jego udzieleniem, zob. L. Pizzolato, Il valore letterario della mistagogia antiochena, „Annali di Scienze Religiose” 11 (2006) 131.

${ }^{11}$ Mistagogia sakramentalna jest zjawiskiem znanym przede wszystkim w Kościele ponicejskim. Szerzej zob. E. Mazza, La mistagogia. La catechesi liturgiche della fine del quarto secolo e il loro metodo, Roma 1996.

${ }^{12}$ Szerzej zob. Ch. Jacob, Zur Kriese der Mystagogie in der Alten Kirche, „Theologie und Philosophie" 66 (1991), 87.

${ }^{13}$ Zdania uczonych na ten temat są podzielone. Według jednych zachowane homilie to tylko „wierzchołek góry lodowej”, por. L. Pizzolato, La nascita della letteratura mistagogica, „Annnali di Scienze Religiose" 7 (2002) 262; zdaniem innych homilie tego typu były znane tylko w niektórych Kościołach, szerzej zob. Jacob, Zur Kriese der Mystagogie in der Alten Kirche, s. 84. 
dla nowo ochrzczonych. Składa się na nie sześć katechez, z których tylko co najwyżej trzy zostały poświęcone Eucharystii. Ich upowszechnienie nie było zamierzone, a zostało wymuszone zaistniałą sytuacją ${ }^{14}$. W De mysteriis tych pouczeń jest jeszcze mniej.

W przypadku św. Augustyna sprawa jest jeszcze bardziej skomplikowana. W całości zachowało się tylko kilka pojedynczych homilii-katechez, wygłoszonych w różnych latach jego działalności duszpasterskiej; kilka zachowało się w stanie fragmentarycznym. Do tego można jeszcze doliczyć jedną o podobnym charakterze, wygłoszoną w uroczystość Pięćdziesiątnicy ${ }^{15}$. Mimo wszystko jest ich jednak relatywnie mało, jak na ponad trzydzieści lat działalności biskupiej św. Augustyna, co dla współczesnych czytelników i analityków stanowi źródło pewnych trudności ${ }^{16}$. Pierwsze bowiem pytanie, jakie się w tych okolicznościach nasuwa, dotyczy powodów, dla których tych katechez jest tak mało. Mając na uwadze fakt, że wystapienia biskupa Augustyna spisywano z dużą skrupulatnością, ten brak jest tym bardziej znaczący. Nie można również tego wytłumaczyć pobłażliwym traktowaniem tej działki duszpasterskiej, bo do sprawy przygotowania katechumenów św. Augustyn przywiązywał dużą wagę, na co dowodem są jego traktaty poświęcone tej tematyce ${ }^{17}$. Mało prawdopodobne, aby tylko w niektórych latach jego duszpasterzowania przygotowywano do chrztu. Nic nam też nie wiadomo, by w przygotowaniach katechumenów pomagali mu prezbiterzy, wyręczający biskupa w głoszeniu katechez ${ }^{18}$. Widocznie były jakieś inne, bliżej nam nieznane powody rezygnacji z zapisywania i publikowania tych katechez. Na ten temat powstają jedynie mniej lub bardziej ugruntowane hipotezy, bez żadnego definitywnego rozstrzygnięcia na korzyść którejś z nich.

Ta szczupłość źródeł rodzi też inną trudność: w oparciu o ten dostępny materiał trudno odtworzyć program i przebieg całego wtajemniczania. Gdyby o eucharystycznych pouczeniach, kierowanych przez Biskupa Hippony do nowo ochrzczonych, sądzić tylko na podstawie zachowanych katechez, to

${ }^{14}$ Zdaniem badaczy, publikację De sacramentis zawdzięczamy stenografowi, który zamierzał bez wiedzy Biskupa opublikować te katechezy, szerzej zob. B. Botte, Introduction, SCh 25bis, Paris 1961, 16-17.

${ }^{15}$ Por. Augustinus, Sermo 272, NBA 32/2, 1042-1044. Niedziela Zesłania Ducha Świętego była też dniem, w którym udzielano chrztu, o ile zachodziła taka potrzeba.

${ }^{16}$ Homilii wielkanocnych zachowało się blisko 30, por. H. Drobner, Augustinus von Hippo. Predigten zum österlichen Triduum (Sermones 218-229D). Einleitung, Text, Übersetzung, Beiträge zum Studium der Kirchenväter. Patrologia XVI, Frankfurt am Main 2006, 60.

${ }^{17}$ Wystarczy tu wspomnieć choćby traktaty: O katechizowaniu poczatkujacych albo Wiara i uczynki.

${ }^{18}$ Taką sytuację znamy z Antiochii, gdzie katechezy głosił Jan Chryzostom, tamtejszy prezbiter, szerzej zob. A. Żurek, Przygotowanie katechumenów i obrzęd chrztu w świetle katechez Jana Chryzostoma, w: Czasy Jana Chryzostoma i jego pasterska pedagogia, red. N. Widok, Opole 2008, 206-207. 
ograniczały się one w zasadzie tylko do jednego wystapienia, w trakcie sprawowania liturgii eucharystycznej w Wielkanoc; tylko ta jedna, niezbyt długa, katecheza miała wystarczyć neofitom za podstawę formacji katechetycznej.

Jeżeli zatem w innych Kościołach było podobnie, jak w Mediolanie czy Hipponie, to można na tej podstawie wnioskować, że na temat Eucharystii, nawet $\mathrm{w}$ ramach katechez mistagogicznych, mówiono $\mathrm{z}$ wielką powściagliwością. Całe wtajemniczenie eucharystyczne to najwyżej kilka katechez w tygodniu wielkanocnym, tak jak to było w Mediolanie, lub nawet jedna katecheza, tak jak to było w Hipponie. Nie miało ono ściśle określonego programu, bo zależało od biskupa, na co zwróci uwagę i do czego ograniczy cały przekaz. Być może, że niektórzy biskupi co roku powtarzali ten sam cykl katechez. A może też, jak zdaje się dowodzić przykład św. Augustyna, biskup co roku zwracał uwagę na nieco inny aspekt misterium eucharystycznego.

3. Mistagogia eucharystyczna w Hipponie. W Hipponie, w czasach św. Augustyna, wtajemniczenie rozpoczynało się w noc paschalną. W uroczystość wielkanocną Msze św. celebrowano w ramach wigilii paschalnej, a potem rankiem w dzień Wielkanocy. Trudno ustalić, czy miało to miejsce w jednym i tym samym miejscu, czy też w różnych ${ }^{19}$. Podczas każdej z tych celebr, biskup zabierał głos na tematy związane z uroczystością i sprawowanymi obrzędami ${ }^{20}$. W sumie, w trakcie Wielkiej Soboty i Niedzieli Wielkanocnej zabierał on być może głos nawet sześć razy: trzykrotnie w czasie liturgii wielkosobotniej, dwa razy w trakcie Mszy św. porannej, i raz jeszcze po południu tego dnia podczas okolicznościowego nabożeństwa ${ }^{21}$.

Msza św. poranna, ze specjalnie dobranymi czytaniami ${ }^{22}$, miała szczególne znaczenie dla nowo ochrzczonych. W jej trakcie bowiem była głoszona specjalna nauka, skierowana do nich, na temat Eucharystii. Bardzo dyskusyjny jest sam moment wygłoszenia, bo w tekście nie ma żadnych szczegółowych informacji na ten temat, a te, które są, pozwalają na różne interpretacje. Ana-

${ }^{19}$ Por. C. Lambot, Les sermons de saint Augustin pour fêtes de la Paques. Liturgie et archeologie, RSR 30 (1956) 237. Chrztu zazwyczaj udzielano poza bazyliką, a ponadto w Hipponie istniało wówczas kilka kościołów, szerzej zob. F. Van der Meer, Sant'Agostino pastore d'anime, Roma 1971, 70-71.

${ }^{20}$ Program ten poznajemy z homilii samego Augustyna, por. Sermo 227, 1, NBA 32/1, 394: „Sermonem ad altare Dei debemus hodie infantibus de sacramento altaris. Tractavimus ad eos de sacramento Symboli, quod credere debeant; tractavimus de sacramento Orationis Dominicae, quomodo petant; et de sacramento fontis et baptismi. Omnia haec et disputata audierunt, et tradita perceperunt; de sacramento autem altaris sacri, quod hodie viderunt, nihil adhuc audierunt; hodie illis de hac re sermo debetur. Propterea hic sermo brevis esse debet, et propter laborem nostrum, et propter aedificationem illorum".

${ }^{21}$ Por. Drobner, Augustinus von Hippo. Predigten zum österlichen Triduum, s. 60. Nie wszystkie ustalenia tam zawarte wydają się absolutnie pewne, stąd należy je traktować z ostrożnością.

${ }^{22}$ Ich uszeregowanie sprawia kłopot, por. C. Lambot, Les sermons de saint Augustin pour fêtes de la Paques, RBen 79 (1969) 164. 
litycy zgodnie utrzymują, że biskup Augustyn głosił tę naukę dopiero po wyjściu katechumenów, i co tego panuje powszechna zgoda ${ }^{23}$. Natomiast dyskusyjny jest konkretny moment liturgii eucharystycznej, w którym Biskup zabierał głos. W oparciu o analizę tekstu, plasuje się tę katechezę albo jeszcze przed konsekracją, albo przed Pater noster, albo nawet jako pouczenie tuż przed Komunią świętą ${ }^{24}$. Była to jedyna, jak się wydaje, katecheza mistagogiczna, głoszona przez Augustyna w danym roku, poświęcona w całości Eucharystii ${ }^{25}$.

Natomiast przez całą oktawę wielkanocną nowo ochrzczeni uczestniczyli wraz z innymi wiernymi w specjalnych nabożeństwach, bo jak zapowiadał w Wielkanoc św. Augustyn: ,tych siedem lub osiem dni, które nadchodzą, poświęca się sakramentom nowo ochrzczonych" ${ }^{26}$. Były to normalne, codzienne Msze święte, ze specjalnie dobranymi czytaniami i homiliami ${ }^{27}$. Porządek tych czytań nie był ścisły i ustalony raz na zawsze, ale zwyczajowo te same czytania były co roku powtarzane. Co najwyżej, można mówić o pewnych modyfikacjach, wprowadzanych periodycznie. W efekcie można mówić o cyklach, których w Hipponie być może było kilka ${ }^{28}$. Pierwszeństwo i miejsce uprzywilejowane miały w liturgii teksty zaczerpnięte z Ewangelii św. Jana i z jego listów. W homiliach kaznodzieja zazwyczaj podejmował tematy związane z tymi czytaniami ${ }^{29}$.

Nowi chrześcijanie ubrani w białe szaty, zajmowali honorowe miejsce w kościele, a dopiero od Niedzieli Białej zajmowali miejsce pośród innych wiernych $^{30}$. Od tego momentu stawali się po prostu ,wiernymi” (fideles), w pełni wprowadzonymi w chrześcijaństwo ${ }^{31}$. Składali białe szaty, w których chodzili od chwili chrztu, a jedyną ich odtąd ozdobą winny być nieskazitelne

${ }^{23} \mathrm{~W}$ tekście katechez brak jednoznacznych wskazówek na ten temat.

${ }^{24}$ Szerzej zob. Drobner, Augustinus von Hippo. Predigten zum österlichen Triduum, s. 412-413; Mazza, La mistagogia, s. 175-176; G. Cuscito, Introduzione, w: Cromazio do Aquileia, Catechesi al popolo, Roma 1979, 233, nr 1 .

${ }^{25}$ Nowo ochrzczeni przychodzili w Wielkanoc jeszcze raz w godzinach wieczornych, ale wtedy nie sprawowano Eucharystii, nauka zaś wówczas wygłoszona, miała już inny temat. Nabożeństwo miało mieć formę „nabożeństwa Słowa Bożego”, por. Drobner, Augustinus von Hippo. Predigten zum österlichen Triduum, s. 57.

${ }^{26}$ Augustinus, Sermo 228, 1, NBA 31/1, 392: „Ex his diebus, septem vel octo qui nunc agentur, Sacramentis Infantium deputantur".

${ }^{27}$ Zazwyczaj czytano fragmenty ewangelii mówiące o tym, co wydarzyło się po zmartwychwstaniu Chrystusa, por. F. Van der Meer, S. Agostino pastore d'anime, Roma 1971, 831.

${ }^{28}$ Por. S. Poque, Les lectures liturgiques de l'octave à Hippone d'après les Traités de S. Augustin sur la Première Épître de S. Jean, RBen 74 (1964) 221.

${ }^{29}$ Szerzej zob. V. Grossi, Gv 20-21 nella catechesi della Chiesa d'Ippona al tempo di S. Agostino, w: Atti del IV Simposio di Efeso su S. Giovanni apostolo, ed. L. Padovese, Roma 1994, 174-189.

${ }^{30}$ Por. Augustinus, Sermo 223, 1, NBA 32/1, 318; Sermo 260, 1, NBA 32/2, 864: „Vos qui baptisati estis, et hodie completis sacramentum octavarum vestrarum [...] qui hodie miscendi sunt populo".

${ }^{31}$ Augustyn precyzyjnie rozróżnia kategorie wśród swoich słuchaczy. Wyróżnia: „katechumenów słuchających” (audientes), „ubiegających się o chrzest” (competentes), „,nowo ochrzczonych” 
obyczaje $^{32}$. Dla niektórych spośród nich była to ostatnia na dłuższy czas obecność w kościele, o czym sam Biskup wspomina:

„Pójdziecie do waszych domów i od tej pory będziemy was rzadko oglądać, co najwyżej z okazji jakiejś uroczystości”’33.

Obecność nowo ochrzczonych w kościele była zauważana przez kaznodzieję przez stosowny zwrot, albo szczególne pouczenie skierowane do nich ${ }^{34}$. Ulubioną nazwą naszego Biskupa, z jaką zwracał się do nowo ochrzczonych, był termin infantes, co w języku polskim najłatwiej oddać przez „,noworodki”, „,nowo narodzeni”, albo ,niemowlęta” ${ }^{35}$. O tym, że nie chodziło tu o zwykłe „noworodki”, Biskup przekonywał szerzej w jednym z kazań, w którym wyjaśniał:

„Nazywają się noworodkami (infantes), ponieważ w pewien sposób narodzili się dla Chrystusa ci, którzy wcześniej narodzeni byli dla świata"36.

Chodzi zatem o „noworodków” w sensie duchowym, czyli nowo ochrzczonych; w sensie fizycznym byli to już ludzie dorośli. Część homilii, wygłaszanych w oktawie wielkanocnej, była skierowana wyłącznie do nich ${ }^{37}$, natomiast w pozostałych pouczenia do nich kierowane zajmuja poczesne miejsce. Wskazania Biskupa dotyczyły przede wszystkim chrześcijańskiego stylu życia. Św. Augustyn przestrzegał przed zachowaniami niegodnymi chrześcijanina: piętnował przykłady złych chrześcijan i zalecał ich unikanie. Temat Eucharystii ograniczał się w tych kazaniach tylko do ,aluzyjnych uwag" ${ }^{38}$. Jedynym sakramentem, do którego częściej w tych dniach kaznodzieja nawiązywał, był chrzest i wynikające $\mathrm{z}$ niego zobowiązania.

4. Katecheza pochrzcielna. W poranek wielkanocny nowo ochrzczeni uczestniczyli już po raz drugi w liturgii eucharystycznej, bo pierwszy raz czynili to zaraz po chrzcie. Wówczas też po raz pierwszy przyjmowali Komunię

(infantes) oraz wiernych (fideles), szerzej zob. É. Lamirande, „Fidelis” et l'ecclesiologie de s. Augustin un theme etrangement neglige, ,Augustinianum” 41 (2001) 169-200.

${ }^{32}$ Por. Augustinus, Sermo 260/C, 7, NBA 32/2, 868.

${ }^{33}$ Augustinus, Sermo 259, 4, NBA 32/2, 838: ,omnes qui ituri estis ad domos vestras, et ex hoc vix nos videbimus, nisi per aliquam sollemnitatem".

${ }^{34}$ Interesujące, że w homiliach głoszonych w oktawie wielkanocnej, Augustyn nie używał nazwy infantes, powtarzał ją dopiero w niedzielę kończącą oktawę, szerzej zob. A. Zwinggi, Die Osternacht bei Augustinus, „Liturgisches Jahrbuch” 20 (1970) 8.

${ }^{35}$ Łac. „infans, -ntis” thumaczy się przez „małe dziecko, niemowlę”, por. J. Sondel, Stownik tacińsko-polski dla prawników i historyków, Kraków 1997, 480.

${ }^{36}$ Augustinus, Sermo 228, 1, NBA 32/1, 392: „Infantes dicuntur, quia modo nati sunt Christo, qui prius nati fuerant saeculo”. W polskich thumaczeniach można spotkać thumaczenie „niemowlęta", co brzmi absurdalnie, gdy tę nazwę skonfrontuje się z treścią katechezy.

${ }^{37}$ Por. Augustinus, Sermones 259, 260, 260A, 260B, NBA 32/2, 830-856.

${ }^{38}$ Por. A. Sage, L'Eucharistie dans la pènsée de s. Augustin, REAug 15 (1969) 226. 
świętą ${ }^{39}$, wysłuchali homilii wielkanocnej, a następnie, w trakcie Mszy św. katechezy poświęconej Eucharystii. Była ona skierowana przede wszystkim do nich, choć we Mszy św. uczestniczyli również inni wierni. Wówczas biskup na początku uroczyście wprowadzał słuchaczy w temat, wyjaśniając im cel i sens katechezy eucharystycznej:

„Pamiętam o mojej obietnicy. Przyrzekłem wam, którzy zostaliście ochrzczeni, mowę w której wyjaśnię Sakrament stołu Pańskiego, który wprawdzie teraz widzicie, a którego minionej nocy staliście się uczestnikami. Winniście wiedzieć, co przyjęliście, co przyjmiecie i co codziennie winniście przyjmować" ${ }^{40}$.

W następnych słowach kaznodzieja skoncentrował się na wyjaśnieniu natury tego, co znajduje się na ołtarzu. Nowo ochrzczeni widzą tam chleb i w kielichu wino, które „uświęcone słowem Bożym” są już Ciałem i Krwią Chrystusa ${ }^{41}$. Katecheza była zatem wygłaszana po konsekracji. W sposób zwięzły i bezdyskusyjny podkreślona została realna obecność Chrystusa. Św. Augustyn nie uzasadniał tej prawdy, a wzmianka o „słowie Bożym” jest tylko delikatnym wskazaniem momentu przeistoczenia. O jakie jednak słowa chodzi i kiedy zostają one wymówione, nowo ochrzczeni już się z katechezy nie dowiadywali; Biskup Hippony zachowywał w tej sprawie zagadkowe milczenie. Być może, jak sądzą niektórzy współcześni komentatorzy, w tradycji afrykańskiej Modlitwa Eucharystyczna i słowa konsekracji nie były publicznie przywoływane ${ }^{42}$.

Zamiast tego św. Augustyn skupiał uwagę słuchaczy na innych ważnych dla niego tematach. Jednym z nich było uświadomienie słuchaczom faktu uczestnictwa w szczególnej ofierze Chrystusa. W jednych katechezach w sposób szerszy, w innych tylko aluzyjnie przypominał:

,jest składana tak czysta i łatwa ofiara [...] przepowiadana przez Proroków, i według łaski Nowego Testamentu ta ofiara chwały Bogu jest ofiarowana, $[\ldots]$ jest to ofiara naszych czasów, a jest nią Ciało i Krew samego Kapłana " ${ }^{43}$.

${ }^{39}$ Podobnie było w uroczystość Zesłania Ducha Świętego, jeśli przy tej okazji udzielano chrztu, por. Augustinus, Sermo 272, 1, NBA 32/2, 1042.

${ }^{40}$ Augustinus, Sermo 227, 1, NBA 32/1, 386: „Memor sum promissonis meae. Promiseram enim vobis, qui baptizati estis, sermonem quo exponerem mensae Dominicae Sacramentum, quod modo etiam videtis et cuius nocte praeterita participes facti estis. Debetis scire quid accepistis, quid accepturi estis, quid quotidie accipere debeatis".

${ }^{41}$ Por. tamże 227, 1, NBA 31/1, 386: „Panis ille quem videtis in altari sanctificatus per verbum Dei, corpus est Christi. Calix ille, immo quod habet calix, sanctificatus per verbum Dei, sanguis est Christi”.

${ }^{42}$ Szerzej zob. M.Y. Perrin, Arcana misteria ou ce que cache la religion. De certains pratiques de l'arcana dans christianisme antique, w: Religonen - die Religie Erfahrungen / Religions - the religions experience, ed. T. Schabert - M. Riedle, Würzburg 2008, 135.

${ }^{43}$ Augustinus, Sermo 228/B,1, NBA 32/1, 398: „tam mundum et facile sacrificium [...] sicut a Prophetis praedictum est, immolatur, et secundum Novi Testamenti gratiam Deo victima laudis offeretur $[\ldots]$ sacrificium nostri temporis corpus et sanguis est ipsius sacerdotis". 
Po takich słowach żaden $\mathrm{z}$ obecnych nie mógł mieć wątpliwości, że chodzi o ofiarę krzyżową Chrystusa, bo Msza św. jest przecież „pamiątką Męki”"44.

Jednak tajemnica Eucharystii ma jeszcze jeden aspekt: Chrystus obecny na ołtarzu pod postaciami chleba i wina, to przecież według Biskupa Hippony, ten sam Chrystus żyjący w Kościele, tylko pod inną postacią. W ten sposób „Augustyn przechodzi w sposób całkiem naturalny od ciała sakramentalnego, spoczywającego na ołtarzu, do Chrystusa totalnego" ${ }^{45}$. Chleb w sposób bardzo widoczny i przemawiający do wyobraźni, ukazuje misterium Kościoła oraz miejsce w nim każdego z jego członków. Powstały z mąki wielu ziaren, stanowi jedność, w żaden sposób nie przypominającą produkt wyjściowy. Ten właśnie wymiar ofiary eucharystycznej starał się uzmysłowić nowo ochrzczonym Hippończyk, ilekroć wygłaszał do nich katechezę pochrzcielną. Dzieje się tak, ponieważ, jego zdaniem, zachodzi „tożsamość ontologiczna między Eucharystią i Kościołem: tak jedno, jak i drugie, są Ciałem Chrystusa" ${ }^{46}$. W efekcie, to co zostaje powiedziane o chlebie eucharystycznym, odnosi się również do chrześcijan. W tym duchu, Augustyn w sugestywny sposób, przekonywał neofitów:

„My także staliśmy się jego Ciałem”47. „Jeżeli jesteście Ciałem Chrystusa i jego członkami, misterium wasze złożone jest na stole Pańskim"48.

Odwołując się do historii powstawania chleba eucharystycznego, która rozpoczyna się od ziarna zboża, które zmielone, zmieszane z mąką powstałą $\mathrm{z}$ innych ziaren, $\mathrm{w}$ procesie wypieku staje się dopiero chlebem, przypomina słuchaczom dzieje ich dojścia do stołu eucharystycznego. Poprzez katechumenat, dzięki działaniu Ducha Świętego, zostali włączeni w Ciało Chrystusa, reprezentowane przez chleb złożony na ołtarzu ${ }^{49}$, a tym samym w Ofiare Chrystusa; obowiązkiem ich zaś jest trwanie w jedności z Chrystusem, co ma być skutkiem przyjmowanej Komunii świętejo ${ }^{50}$.

Eklezjalny wymiar zarówno uczestnictwa w Eucharystii, jak też przyjmowania Komunii św., stanowi esencjalny element pochrzcielnej katechezy św. Augustyna. Wiarę w to, że uczestniczy się w ofierze Ciała Chrystusa, którego przez chrzest stało się członkiem, chrześcijanin ma wyrazić wypowiadając w sposób świadomy i odpowiedzialny „Amen” podczas aktu przyjmowania Ciała i Krwi Pańskiej. Jasno brzmią słowa Kaznodziei:

${ }^{44}$ Tak Augustyn nazwał Mszę św. w De diversis quaestionibus 83, 61, 2, NBA 6/2, 134.

${ }^{45}$ S. Poque, Introduction, SCh 116, Paris 2003, 84.

${ }^{46}$ Mazza, La mistagogia, s. 180.

${ }^{47}$ Augustinus, Sermo 229, 1, NBA 32/1: „Nam et nos corpus ipsius facti sumus”.

${ }^{48}$ Augustinus, Sermo 272, 1, NBA 32/2: „Si ergo vos estis Corpus Christi et membra, mysterium vestrum in mensa Dominica positum est".

${ }^{49}$ Por. Augustinus, Sermo 229, 1, NBA 32/1, 404; 227, 1, NBA 32/1, 386; 272, 1, NBA 32/2, 1044.

${ }^{50}$ Por. Augustinus, Sermo 228/B,3, NBA 32/1, 400: „manducate vinculum vestrum, ne vobis viles videamini $[\ldots]$ Sicut in vos hoc convertitur, cum id manducatis et bibitis, sic et vos in corpus Christi convertimini”. 
„Słyszysz «Ciało Chrystusa» i odpowiadasz «Amen». Bądź zatem członkiem Ciała Chrystusa, aby prawdziwe było twoje «Amen» [...]. Bądźcie tym, co widzicie, i przyjmijcie to, czym jesteście" ${ }^{51}$.

Trudno w bardziej syntetyczny sposób wyrazić związek między Eucharystią i Kościołem. Realizuje się on w trakcie sprawowania liturgii eucharystycznej, pod znakami sakramentalnymi chleba i wina. To jest właśnie jeden $\mathrm{z}$ istotnych wymiarów misterium, które starał się odsłonić kaznodzieja.

Katechezy, które św. Augustyn corocznie wygłaszał podczas Mszy św. w Niedzielę Wielkanocna, można nazwać „kazaniami pierwszokomunijnymi”, bo były skierowane rzeczywiście do tych, którzy w Wigilię Paschalną po raz pierwszy przyjmowali Komunię świętą 5 ; ich celem było wprowadzenie w misterium. Natomiast cała edukacja eucharystyczna na tym się nie kończyła. Wierzący, którzy już regularnie uczestniczyli w sprawowaniu Eucharystii, otrzymywali dalsze pouczenia, dotyczące zwłaszcza właściwego przygotowania i przyjmowania Komunii świętej. Do tych celów Biskup Hippony wykorzystywał zwłaszcza okazje, które stwarzało czytanie tych tekstów ewangelii, które wprost nawiązywały do Eucharystii ${ }^{53}$. Na temat Eucharystii wypowiadał się również w innych swoich tekstach, ale to, co zawarł w katechezach zarówno przedchrzcielnych jak też pochrzcielnych - należy niewątpliwie do istotniejszych elementów jego doktryny eucharystycznej.

\section{THE EUCHARISTIC CATECHESIS OF SAINT AUGUSTINE}

\section{(Summary)}

Preparation for participating in the Eucharist took place in the fourth and fifth centuries as part of pre-baptismal catechesis, and to a more degree as part of mystagogical catechesis which took place after baptism. A few of such catecheses have been preserved after saint Augustine. He preached them at Easter. In these catecheses he tried to make neophytes aware of the real presence of Christ in Bread and Wine. He justified it using biblical texts especially Christ's statements about ,the living bread”. The main task and duty of Christians was to wake up in the faith and receive the Eucharist worthily.

${ }^{51}$ Augustinus, Sermo 272, 1, NBA 32/2, 1044: „Audis enim: «Corpus Christi»; et respondes: «Amen». Esto membrum corporis Christi, ut verum sit «Amen» [...]. Estote quod videtis, et accipite quod estis".

${ }_{52}$ Por. M. Comeau, Les prédications Pascale de Saint Augustin, RSR 23 (1933) 263.

${ }^{53}$ Jako przykład można wskazać homilie na temat „Mowy eucharystycznej” Chrystusa (J 6, 2271), której św. Augustyn poświęcił trzy homilie. Są one uważane za najdłuższe jego wypowiedzi na temat Eucharystii, por. F. M. Berrouard, L'être sacramentel de l'Eucharistie selon s. Augustin. Commentaire de Jean VI, 60-63 dans le „Tractatus XXVII, 1-6 et 11-12 in Ioannis Evangelium”, NRTh 99 (1977) 703. 